\title{
PENINGKATAN KINERJA GURU DALAM PERANCANGAN PEMBELAJARAN MELALUI SUPERVISI AKADEMIK KEPALA SD NEGERI 10 CAKRANEGARA SEMESTER SATU TAHUN PELAJARAN 2018/2019
}

\author{
Husni Tamrin \\ Kepala SD Negeri 10 Cakranegara.
}

\begin{abstract}
Abstrak. Sebagai pengajar atau pendidik, guru merupakan salah satu faktor penentu keberhasilan setiap upaya pendidikan. Itulah sebabnya setiap inovasi pendidikan, khususnya dalam kurikulum dan peningkatan sumber daya manusia yang dihasilkan dari upaya pendidikan selalu bermuara pada faktor guru. Hal ini menunjukkan bahwa betapa eksisnya peran guru dalam dunia pendidikan. Agar dapat mengajar efektif, guru harus mampu meningkatkan kesempatan belajar bagi peserta didik (kuantitas) dan meningkatkan mutu (kualitas) mengajar.Tujuan diadakannya Penelitian Tindakan Sekolah (PTS) ini adalah untuk mengetahui sejauhmana peningkatan kinerja guru dalam perancangan pembelajaran melalui supervisi akademik kepala sekolah di SD Negeri 10 Cakranegara Kota Mataram Semester Satu Tahun Pelajaran 2018/2019. Dari hasil tindakan yang dilakukan terbukti dapat meningkatkan kinerja guru dengan mencapai standar ideal. Hasil penelitian pada siklus I observasi Kepala Sekolah rata-rata $(3,30)$, observasi guru rata-rata $(3,50)$ dan hasil supervisi akademik guru kelas rata-rata nilai $(69,08)$. Pada siklus II observasi kepala Sekolah rata-rata $(4,60)$, observasi guru rata-rata $(4,67)$ dan hasil supervisi akademik di sasaran rata-rata nilai $(90,19)$. Indikator keberhasilan telah tercapai, penelitian di nyatakan berhasil dan dihentikan pada siklus II.Kesimpulan; Hasil penelitian tindakan ini menunjukkan bahwa penerapan supervisi akademik kepala sekolah dapat meningkatkan kinerja guru dengan ketuntasan mencapai 100\%. Dengan demikian penerapan supervisi akademik kepala sekolah efektif meningkatkan kinerja guru dalam perancangan pembelajaran di SD Negeri 10 Cakranegara.
\end{abstract}

Kata kunci : Supervisi akademik - Kinerja Guru

\section{PENDAHULUAN}

\section{Latar Belakang}

Sebagai pengajar atau pendidik, guru merupakan faktor penentu keberhasilan setiap upaya pendidikan. Itulah sebabnya setiap adanya inovasi pendidikan, khususnya dalam kurikulum dan peningkatan sumber daya manusia yang dihasilkan dari upaya pendidikan selalu bermuara pada faktor guru. Hal ini menunjukkan bahwa betapa eksisnya peran guru dalam dunia pendidikan. Demikian pun dalam upaya membelajarkan siswa guru dituntut memiliki multi peran sehingga mampu menciptakan kondisi belajar mengajar yang efektif. Belajar mengajar dikatakan efektif dapat dilihat dari sudut prestasi, yaitu mampu menampung masukan yang banyak dan menghasilkan tamatan yang banyak, bermutu dalam arti mampu bersaing dipasaran atau lapangan kerja yang ada dan diperlukan. Efektivitas proses belajar mengajar ini dapat dilihat pula dari sudut proses pendidikan, meliputi kegairahan atau motivasi belajar yang tinggi pada peserta didik.

Dalam penelitian ini penulis mencoba untuk mengkaji dan menggali supervisi kepala sekolah yang berkaitan dengan kinerja guru, disebabkan oleh; 1) adanya kecendrungan melemahnya kinerja guru, dimana berdasarkan pengalaman penulis menjadi kepala di SD Negeri 10 Cakranegara yaitu terjadinya guru yang membolos mengajar, guru yang masuk kelas yang tidak tepat waktu, guru mengajar tidak mempunyai persiapan mengajar, guru tidak punya absensi siswa, 2) adanya pelaksanaan supervisi yang dilakukan kepala 
sekolah belum dilaksanakan dengan sebaikbaiknya kepada guru, 3) adanya penurunan kinerja guru merupakan salah satu penyebab menurunnya nilai UASBN siswa di SD Negeri 10 Cakranegara. Oleh karena itu perlu diungkap tentang supervisi kepala sekolah terhadap peningkatan kinerja guru di SD Negeri 10 Cakranegara. Oleh karena itu penulis perlu melakukan penelitian sebagai upaya peningkatan kinerja guru melalui Penelitian Tindakan Sekolah (PTS) dengan judul "Peningkatan Kinerja Guru Dalam Perancangan Pembelajaran Melalui Supervisi Akademik Kepala SD Negeri 10 Cakranegara Semester Satu Tahun Pelajaran 2018/2019".

\section{Identifikasi masalah}

- Bagaimana bentuk pembinaan kepala sekolah upaya peningkatan kinerja guru dalam menyusun Rencana Pelaksanaan Pembelajaran (RPP)

- Sejauh mana peran dan fungsi kepala sekolah membantu guru untuk meningkatkan kinerjanya

- Faktor-faktor apa saja yang dapat mempengaruhi upaya peningkatan kinerja guru dalam menyusun Rencana Pelaksanaan Pembelajaran (RPP)

- Bagaimana efektivitas supervisi akademik kepala sekolah upaya peningkatan kinerja guru dalam menyusun Rencana Pelaksanaan Pembelajaran (RPP)

\section{Rumusan Masalah}

- Bagaimana peningkatan kinerja guru dalam menyusun Rencana Pelaksanaan Pembelajaran (RPP) melalui supervisi akademik kepala SD Negeri 10 Cakranegara semester satu tahun pelajaran 2018/2019?

- Bagaimana efektivitas supervisi akademik kepala SD Negeri 10 Cakranegara upaya meningkatkan kinerja guru dalam menyusun Rencana Pelaksanaan Pembelajaran semester satu tahun pelajaran 2018/2019 di SD Negeri 10 Cakranegara?

\section{Tujuan Penelitian}

- Peningkatan kinerja guru dalam perencanaan pembelajaran melalui supervisi akademik kepala SD Negeri 10 Cakranegara semester satu tahun pelajaran 2018/2019.

- Efektivitas supervisi akademik kepala sekolah meningkatkan kinerja guru dalam perencanaan pembelajaran di SD Negeri 10 Cakranegara semester satu tahun pelajaran 2018/2019.

\section{Manfaat penelitian}

- Memberikan sumbangan pemikiran dan tolak ukur kajian pada penelitian lebih lanjut yaitu berupa alternatif yang dapat dipertimbangkan dalam usaha memperbaiki mutu pendidikan dan mempertinggi interaksi belajar mengajar, khususnya dalam pembinaan/supervisi kepala sekolah.

- Dapat dipertimbangkan dalam melaksnakan pembinaan kepada guru dibidang yang lain terutama dalam meningkatkan kinerja guru.

- Memberikan kemudahan bagi guru dalam meningkatkan kinerjanya melaksanakan tugas pembelajaran di sekolah terutama dalam perancangan pembelajaran guru.

- Dapat digunakan sebagai bahan pertimbangan strategi pelatihan bagi guru dalam rangka meningkatkan mutu sekolah.

- Dapat dijadikan bahan pertimbangan bagi sekolah dalam rangka memajukan dan meningkatkan prestasi sekolah yang dapat disampaikan dalam pembinaan guru ataupun kesempatan lain bahwa pembinaan/supervisi kepala sekolah dapat diterapkan dalam upaya meningkatkan kinerja guru dalam perancangan pembelajaran sehingga peningkatan capaian mutu sekolah dapat dicapai.

\section{KAJIAN PUSTAKA \\ Kinerja guru dan Indikatornya}

Istilah kinerja dapat diterjemahkan dalam performance atau unjuk kerja, artinya kemampuan yang ditampilkan seseorang terhadap pekerjaannya pada tempat ia bekerja. Kinerja merupakan suatu kinerja yang esensial 
terhadap keberhasilan suatu pekerjaan. Karena itu suatu kinerja yang efektif bagi setiap individu perlu diciptakan sehingga tujuan lembaga dapat tercapai secara optimal. Menurut Fattah (1996) kinerja diartikan sebagai ungkapan kemajuan yang didasari oleh pengetahuan, sikap, keterampilan dan motivasi dalam menghasilkan suatu pekerjaan. Dengan demikian dapat disimpulkan bahwa kinerja adalah hasil kerja seseorang yang mencerminkan prestasi kerja sebagai ungkapan pengetahuan, sikap dan keterampilan.

Kinerja guru sangat terkait dengan efektifitas guru dalam melaksanakan fungsinya oleh Medley dalam Depdikbud (1984) dijelaskan bahwa efektifitas guru yaitu: (1) memiliki pribadi kooperatif, daya tarik, penampilan amat besar, pertimbangan dan kepemimpinan, (2) menguasai metode mengajar yang baik, (3) memiliki tingkah laku yang baik saat mengajar, dan (4) menguasai berbagai kompetensi dalam mengajar. Evaluasi kinerja guru mutlak dilakukan, karena masih terdapat banyak kinerja guru yang kurang memadai, disamping itu guru dituntut dapat mengikuti perkembangan ilmu pengetahuan, teknologi dan seni yang terus berkembang pula dengan pesat. Istilah kinerja berasal dari bahasa inggris yaitu performance, berarti hasil kerja atau unjuk kerja yang dicapai seseorang atau kelompok orang/organisasi tertentu. Istilah kinerja dapat diterjemahkan dalam unjuk kerja, artinya kemampuan yang ditampilkan seseorang terhadap pekerjaannya di tempat ia bekerja. Kinerja merupakan suatu hal yang sangat esensial terhadap keberhasilan suatu pekerjaan. Pada hakikatnya orang bekerja untuk memenuhi kebutuhan atas dorongan tertentu. Kebutuhan dipandang sebagai penggerak atau pembangkit perilaku, sedangkan tujuannya berfungsi untuk menggerakkan perilaku. Karena itu suatu kinerja yang efektif bagi setiap individu, perlu diciptakan sehingga tujuan lembaga dapat tercapai secara optimal.

\section{Perancangan Pembelajaran}

Perencanaan pembelajaran yang mendidik perlu mengikuti prosedur yang tepat agar rencana tersebut sesuai dengan aturan yang berlaku dan sesuai Badan Standar Nasional Pendidikan (BSNP), dalam pedoman penyusunan KTSP mengemukakan langkahlangkah yang ditempuh dalan pengembangan silabus mata pelajaran adalah (1) mengkaji standar kompetensi dan kompetensi dasar, (2) mengidentifikasi nateri pokok pembelajaran, (3) mengembangkan kegiatan pembelajaran, (4) merumuskan indikator pencapaian kompetensi, (5) menetapkan jenis penilaian berdasarkan indikator pencapaian kimpetensi, menentukan alokasi waktu tiap kegiatan pembelajaran, dan (7) menentukan sumber belajar.

Pada Prinsipnya pembelajaran yang mendidik merupakan pembelajaran yang mengacu dan didasarkan pada penguasaan atau pencapaian Standar kompetensi lulusan (SKL) yang telah ditetapkan. Agar peserta didik menguasai atau mencapai kompetensi yang telah ditentukan, guru perlu memahami secara tepat perangkat kemampuan yang harus dikuasai oleh peserta didik. Penguasaan atau pencapaian kompetensi dapat diindikasikan sebagai penguasaan pengetahuan, Penguasaan ketrampilan dan kecendrungan kepribadian tertentu. Jadi standar kompetensi adalah kemampuan seseorang dalam bidang tertentu agar dapat ditampilkan atau didemonstrasikan dengan cara yang benar dan karakteristik kepribadian yang mendukung.

Guru, didalam menyelenggarakan proses pembelajaran yang mendidik dituntut untuk menguasai standar kompetensi guru. Menurut PP 19 Tahun 2005 pasal 28 ayat (3), Standar kompetensi yang harus di kuasai seirang pendidik (guru) mencakup kompetensi pedagogik, kepribadian, profesional, dan sosial. Pada pendekatan pasal 28 ayat (3) tersebut, yang dimaksud dengan kompetisi pedagogik adalah kemampuan mengelola pembelajaran peserta didik yang meliputi pemahaman 
terhadap peserta didik, perancangan dan pelaksanaan pembelajaran, penilaian hasil belajar, dan pengembangan peserta didik untuk mengaktualisasikan berbagai potensi yang dimilikinya. Kompetensi kepribadian adalah kemampuan kepribadian yang mantap, stabil, dewasa, arif dan berwibawa, menjadi teladan bagi peserta didik, dan berakhlak mulia. Kompetensi profesional adalah kempuan penguasaan materi pembelajaran secara luas dan mendalam, yang menginginkannya membimbing peserta didik memenuhi Standar kompetensi yang ditetapkan dalam standar nasinal pendidikan. Adapun kompetensi sosial adalah kemampuan pendidik sebagai bagian dari masyarakat untuk berkomunikasi dan bergaul secara efektif dengan peserta didik, sesama pendidik, tenaga kependidikan, orang tua/wali peserta didik dan masyarakat sekitar.

Dalam pelaksanaann pembelajaran yang mendidik, guru perlu berpegang pada rencana pembelajaran yang disusun sebelumnya. Rencana pembelajaran menjadi panduan yang harus digunakan dalam pembelajaran, karena didalam rencana pembelajaran tersebut telah ditetapkan tujuan pembelajaran, materi pembelajaran, kgiatan pembelajaran, dan penilaian pembelajaran. Bayangkanlah, jika kita melakukan perjalanan tanpa menetapkan tempat yang dituju, tentunya perjalanan tidak akan terarah. Perjalanan yang dilakukan sangat ditentukan oleh lokasi yang dituju. Penetapan lokasi yang dituju tersebut menyebabkan kita melakukan perjalanan dengan penuh kesadaran. Lain halnya apabila perjalanan tidak berdasarkan lokasi yang dituju, adda kemungkinan kesadaran kadang-kadang hilang atau tidak berfungsi. Hal ini mungkin saja terjadi didalam proses pembelajaran, karena apabila pembelajaran dikelola guru tanpa berpegang pada rencana pembelajaran maka ada kemungkinan akan berlangsung dalam suasana atau kondisi yang tidak disadari oleh guru.

Jurnal Ilmiah Mandala Education

\section{Supervisi Akademik Kepala Sekolah}

Supervisi akademik adalah kemampuan Kepala Sekolah dalam melaksanakan Pembinaan akademik yakni menilai dan membina guru dalam rangka mempertinggi kualitas proses pembelajaran yang dilaksanakannya, agar berdampak terhadap kualitas hasil belajar siswa.Supervisi akademik intinya adalah membina guru dalam meningkatkan mutu proses pembelajaran. Oleh karena itu, sasaran supervisi akademik adalah guru dalam proses pembelajaran, yang terdiri dari materi pokok dalam proses pembelajaran, penyusunan silabus dan RPP, pemilihan strategi/metode/teknik pembelajaran, penggunaan media dan teknologi informasi dalam pembelajaran, menilai proses dan hasil pembelajaran serta penelitian tindakan kelas. Oleh karena itu, tujuan umum pembinaan Kepala Sekolah melalui supervisi akademik ini adalah (1) menerapkan teknik dan metode supervisi akademik di sekolah, dan (2) mengembangkan kemampuan dalam menilai dan membina guru untuk mempertinggi kualitas proses pembelajaran yang dilaksanakannya agar berdampak terhadap kualitas hasil belajar siswa.

2. Sifat-Sifat Supervisi Akademik Kepala Sekolah

Untuk mencapai tujuan yang telah ditetapkan dalam pembinaan supervisi akademik maka sifat sebagai seorang kepala sekolah dalam melaksanakan supervisi akademik harus memiliki kualitas sebagai berikut:

a) Mendengarkan dengan sabar

b) Menunjukkan keterampilan dengan jelas

c) Menawarkan insentif atau dorongan dengan tepat

d) Mempertimbangkan reaksi dan pemahaman dengan tepat

e) Menjelaskan, merangsang (stimulating) dan memuji secara simpatik dan penuh perhatian

f) Meningkatkan pengetahuan sendiri secara berkelanjutan 


\section{Tujuan Supervisi Akademik}

Supervisi instruksional bertujuan untuk meningkatkan pertumbuhan, pengembangan, interaksi, penyelesaian masalah yang bebas kesalahan, dan sebuah komitmen untuk membangun kapasitas guru. Cogan (1973) dan Goldhammer (1969), penyusun kerangka supervisi akademik, meramalkan praktek yang akan memposisikan guru sebagai pembelajar aktif. Lebih lanjut, Cogan menegaskan bahwa guru memiliki kemampuan menjadi penanggung jawab profesional dan lebih daripada itu ia mampu menjadi "penganalisis kinerjanya sendiri, terbuka untuk membantu orang lain, dan mengarahkan diri sendiri". Unrah dan Turner (1970) mengatakan bahwa sepervisi sebagai "sebuah proses social dari stimulasi, pengasuhan, dan memprediksi pengembangan professional guru" dan kepala sekolah sebagai "penggerak utama dalam pengembangan secara optimum kondisi pembelajaran". Apabila guru belajar dari memeriksa praktiknya seendiri dengan bantuan teman sejawat atau kepala sekolah, pembelajarannnya menjadi lebih personal dan oleh karena itu lebih kuat.

Maksud dari supervisi akademik adalah formatif, sesuai dengan proses yang sedang berjalan, proses pemngembangan, dengan pendekatan yang berbeda yang memungkinkan guru untuk belajar dari cara penganalisisan dan perefleksian praktik di kelas mereka dengan pembinaan kepala sekolah atau professional lainnya (Glatthorn, 1984, 1990, Glickman, 1990). Sebaliknya, maksud dari evaluasi adalah sumatif; pengamatan kelas dan penilaian kinerja professional lainnya mengarah pada pertimbangan final atau rating keseluruhan (mis, $\mathrm{M}=$ memuaskan, $\mathrm{B}=$ baik, $\mathrm{PP}=$ Perlu peningkatan). McGreal (1983) memperjelas bahwa seluruh supervisi mengarah ke evaluasi dan kepala sekolah tidak dapat mengevaluasi guru sebelum mereka melakukan pengamatan terhadap guru di dalam kelasnya.

\section{Hipotesis Tindakan}

- Kinerja guru dalam perancangan pembelajaran dapat ditingkatkan melalui supervisi akademik kepala sekolah SD Negeri 10 Cakranegara Kota Mataram semester satu tahun pelajaran 2018/2019.

- Supervisi akademik kepala sekolah efektif meningkatkan kinerja guru dalam perancangan pembelajaran di SD Negeri 10 Cakranegara Kota Mataram semester satu tahun pelajaran 22018/2019.

\section{METODE PENELITIAN \\ Subyek Penelitian}

Subyek dalam penelitian ini adalah guru SD Negeri 10 Cakranegara Kota Mataram tempat peneliti bertugas sebagai kepala sekolah tahun pelajaran 2018/2019. Jenis penelitian ini adalah Penelitian Tindakan Sekolah (PTS) melalui penerapan supervisi akademik. Jumlah guru yang menjadi obyek dalam penelitian sebanyak 6 orang guru.

\section{Setting Penelitian}

- Penelitian ini dilakukan di SD Negeri 10 Cakranegara pada semester satu tahun pelajaran 2018/2019.

- Guru yang menjadi binaan ada 6 (enam) yaitu guru kelas I, II, III, IV, V, dan VI.

- Penelitian ini dilakukan bagi guru PNS maupun non PNS (honorer) yang mengajar sebagai guru kelas.

\section{Rancangan Penelitian.}

Dalam pelaksanaan tindakan, rancangan dilakukan dalam 2 siklus yang meliputi; a) perencanaan, 2) tindakan, 3) pengamatan, 4) refleksi. Rancangan penelitian tindakan sekolah (PTS) menurut (Arikunto, Suharsimi, 2007;74) adalah seperti gambar berikut: 


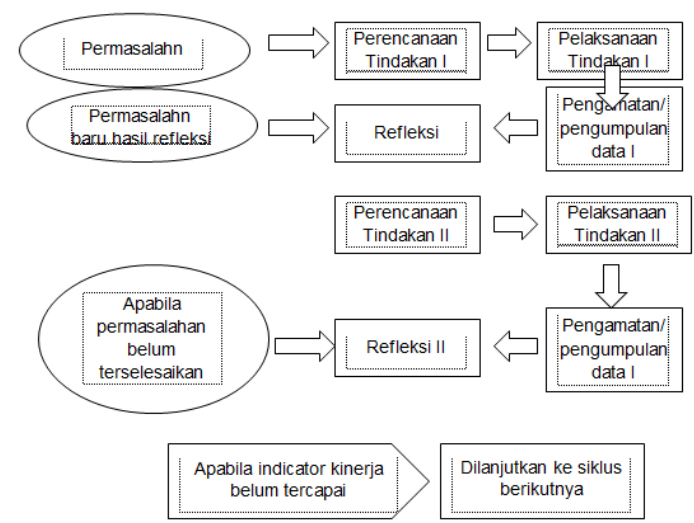

SIKLUS I

Tahap I : Perencanaan Tindakan

1.1. Menyusun materi pembinaan

1.2. Menetapkan scenario dan langkahlangkah pembinaan yang tertuang dalam Rencana Pelaksanaan pembinaan (RPP)

1.3. Menyusun instrument observasi kepala sekolah dan observasi guru

1.4. Menentukan jadwal kegiatan pembinaan

1.5. Menyusun pedoman analisa data hasil observasi dan tugas individu.

Tahap II. Pelaksanaan Tindakan

Pada kegiatan pembinaan secara

berkelompok yang kegiatannya adalah :

2.1. Menyampaikan materi tentang tata cara perancangan pembelajaran.

2.2. Melaksanakan diskusi kelompok kecil dalam penyusunan RPP.

2.3. Memberikan bimbingan secara berkelompok/perorangan.

2.4. Memberikan solusi terhadap permasalahan yang dihadapi oleh guru

2.5. Memberikan penguatan/reward

2.6. Memberikan tugas individual.

Pada kegiatan pembinaan individual yang dilakukan secara bergiliran, dengan cara peneliti mendekati guru satu persatu dalam kelompok untuk membimbing secara individual agar permasalahan-ppermasalahan dapat dipecahkan dengan baik dan benar.

Tahap III. Observasi/pengumpulan Data

3.1. Pengamatan terhadap aktifitas guru peserta pembinaan

3.2. Pengamatan terhadap kinerja guru dalam perancangan pembelajaran.

Jurnal Ilmiah Mandala Education
3.3. Menilai hasil kerja guru secara individual Tahap IV. Refleksi

4.1. Renungan atas data hasil observasi dan hasil kerja secara individual.

4.2. Pengolahan data hasil penelitian dan mencocokkan dengan indikator keberhasilan.

4.3. Rencana perbaikan dan penyempurnaan

4.4. Memberikan penguatan atas hasil yang diperolehnya.

4.5. Rencana tindak lanjut.

SIKLUS II

Jenis kegiatan pada siklus II ini pada dasarnya sama dengan siklus I, bedanya hanya terjadi perbaikan/penyempurnaan dalam pelaksanaannya.

Variabel Penelitian

Variabel Harapan

Peningkatan kinerja guru dalam perancangan pembelajaran (penyusunan RPP)

Variabel Tindakan : Penerapan supervisi kepala sekolah.

Sumber Data Dan Teknik Pengumpulan Data

Sumber Data

1. Guru

: Diperoleh data tentang peningkatan kinerja guru dalam perancangan pembelajaran

2. Kepala Sekolah : diperoleh data tentang penerapan supervisi akademik kepala sekolah

\section{Teknik Pengumpulan Data}

- Data guru:

1. Diambil dari aktivitas selama pembimbingan dalam kelompok

2. Diambil dari nilai haasil penyusunan Rencana Pelaksanaan Pembelajaran (RPP)

- Data Kepala Sekolah

1. Berupa catatan harian selama pembimbingan

2. Hasil observasi/pengamatan dari observer yang dalam hal ini adalah pengawas Pembina SD Negeri 10 Cakranegara. 


\section{Indikator Keberhasilan}

Penelitian Tindakan Sekolah (PTS) yang dilakukan dalam 2 siklus dianggap sudah berhassil apabila terjadi peningkatan kinerja guru dalam perancangan pembelajaran pembelajaran mencapai $85 \%$ (dari guru yang diteliti) telah mencapai ketuntasan dengan nilai rata-rata 75 . Berarti telah memenuhi harapan ideal seperti yang diisyaratkan dalam manajemen berbasis sekolah (MBS) dengan standar ideal minimal 75.

\section{HASIL DAN PEMBAHASAN \\ Deskripsi Siklus I \\ Tahap Perencanaan}

Pada tahapan ini peneliti melakukan: 1) menyusun materi pembinaan, 2) menetapkan skenario dan langkah-langkah pembinaan yang tertuang dalam Rencana Pelaksanaan Pembinaan (RPP), 3) menyusun instrumen observasi kepala sekolah dan instrumen observasi guru, 4) menentukan jadwal kegiatan pembinaan, 5) menyusun pedoman analisis data.

\section{Tahap Pelaksanaan}

- Pembinaan klasikal/kelompok; 1) menyampaikan materi tentang tata cara perancangan pembelajaran, 2) melaksanakan diskusi kelompok kecil dalam penyusunan RPP, 3) memberikan bimbingan secara berkelompok, 4) memberikan solusi terhadap permasalahan yang dihadapi oleh guru, 5) memberikan penguatan/reward, dan 6) memberikan tugas individual.

- Pembinaan individual, jenis kegiatannya adalah; 1) pada saat guru bekerja dalam kelompok/diskusi kelompok peneliti membimbing guru yang mengalami kesulitan dalam penyusunan RPP secara kelompok kecil/perorangan, 2) memberikan solusi/pemecahan terhadap kesulitan yang dirasakan secara individual, 3) kegiatan seterusnya sampai ke 6 (enam) guru peserta pembinaan mendapatkan giliran pembinaan secara individual

\section{Tahap Observasi}

Hasil Observasi Kepala Sekolah memperoleh skor rata-rata sebesar 3,40, observasi guru memperoleh skor rata-rata sebesar 3,33, dan nilai individual guru memperoleh nilai rata-rata sebesar 69,08.

\section{Tahap Refleksi}

Pada tahapan ini peneliti merenung atas perolehan data hasil observasi kepala sekolah, observasi guru, dan nilai individual hasil perancangan pembelajaran. Selanjutnya peneliti mengolah data dan hasilnya di cocokkan dengan indikator keberhasilan dengan rincian sebagai berikut: Hasil Observasi Kepala Sekolah $(3,40)$, Hasil Observasi Guru $(3,33)$, dan Rata-rata Nilai Individual $(69,08)$.

Karena perolehan hasil masih dibawah indikator keberhasilan yang direncanakan, maka pada siklus berikutnya akan diadakan perbaikan dan penyempurnaan dari serangkaian kegiatan pembinaan secara klasikal maupun secara individual, namun demikian peneliti tetap memberikan penguatan atas hasil yang diperolehnya dan penelitian dilanjutkan pada siklus II dengan mengoptimalkan semua jenis tindakan dalam pembinaan sehingga di peroleh hasil yang memuaskan.

\section{Deskripsi Siklus II \\ Tahap Perencanaan}

Tahapan perencanaan pada siklus II jenis kegiatannya masih sama dengan siklus I, bedanya pada siklus II ini lebih memfokuskan perbaikan/penyempurnaan dalam proses pembinaan klasikal maupun pembinaan individual, yang jenis kegiatannya adalah: 1) menyempurnakan materi pembinaan, 2) menetapkan skenario pembinaan, 3) menetapkan instrumen observasi kepala sekolah maupun observasi guru, 4) menetapkan jadwal kegiatan pembinaan, 5) menyusun pedoman analisis data hasil observasi dan tugaas individu.

\section{Tahap Pelaksanaan}

- Pembinaan klasikal/kelompok; 1) menyampaikan/merefleksi hasil perolehan data pada siklus I, 2) menjelaskan ulang tata 
cara perancangan pembelajaran secara lebih rinci, 3) perbaikan RPP secara berkelompok/diskusi kelompok, 4) memberikan refleksi terhadap hasil kerja kelompok yang mengalami kendala, 5) memberikan penghargaan/reward dan 6) memberikan tugas individual.

- Pembinaan individual/kelompok kecil; 1) pada saat proses kerjasama dalam kelompok, peneliti mengamati/mencermati hasil kerja secara individual, 2) memberikan bimbingan/merefleksi terhadap hasil kerja individual yang masih mengalami kendala, 3) begitu seterusnya sampai semua guru peserta pembinaan mendapatkan pembinaan secara individual.

\section{Tahap Observasi/Pengumpulan Data}

Hasil Observasi Kepala Sekolah memperoleh skor rata-rata sebesar 4,60, observasi guru memperoleh skor rata-rata sebesar 4,67, dan nilai individual guru memperoleh nilai rata-rata sebesar 90,19.

\section{- Tahap Refleksi}

Pada tahapan ini peneliti merenung atas perolehan data hasil observasi kepala sekolah, observasi guru, dan nilai individual hasil perancangan pembelajaran. Kemudian di olah engan menggunakan rumus yang telah ditetapkan. Hasil perolehan data di cocokkan dengan indikator keberhasilan dengan perolehan data sebagai berikut: Hasil Observasi Kepala Sekolah $(4,60)$, Hasil Observasi Guru $(4,67)$, Rata-rata Nilai Individual $(90,19)$.

Karena perolehan hasil siklus II sudah melebihi indikator keberhasilan, maka tidak perlu ada perbaikan/penyempurnaan dalam perancangan pembelajaran, selanjutnya peneliti memberikan penghargaan/reward kepada semua guru peserta pembinaan karena dari 6 (enam) guru kelas 100\% sudah memperoleh nilai rata-rata $\geq 80,00$. Penelitian dinayatakan berhasil dan tindakan dihentikan pada siklus II.

\section{PEMBAHASAN \\ SIKLUS I}

\section{Tahap Perencanaan}

Dalam

penyusunan

materi

pendampingan, menetapkan skenario dan langkah-langkah pendampingan, dan perencanaan penyusunan instrumen observasi kepala sekolah dan instrumen observasi guru peneliti mengalami beberapa kendala yaitu dalam pendampingan klasikal maupun pendampingan individual. Faktor penyebabnya adalah karena peneliti masih belum menemukan strategi yang tepat dan diterima oleh peserta. Solusi yang dilakukan oleh peneliti adalah dengan meminta petunjuk dari pengawas pembimbing, sekolah diberikan petunjuk dan arahan nyata maka pendampingan klasikal dan individualpun terlaksana dengan baik.

\section{Tahap Pelaksanaan}

Kegiatan nyata dalam pelaksanaan pembinaan dapat dijabarkan sebagai berikut: pada saat menyampaikan materi tentang tata cara perancangan pembelajaran mengalami kendala yang disebabkan peneliti masih kekurangan sumber/buku literatur, sehingga berdampak tertundanya dalam penyusunan, solusi yang dilakukan peneliti mencari beberapa buku literatur terkait dengan tata cara penyusunan RPP termasuk mencari di internet, akhirnya materi pembinaan dapat tersusun dengan baik. Dalam pelaksanaan bimbingan pada saat peserta pembinaan melakukan diskusi/kerjasama dalam kelompok, peneliti berkeliling memberikan bimbingan dan solusi terhadap peserta yang mengalami kesulitan. Pada kegiatan ini peneliti tidak mengalami hambatan/permasalahan artinya berjalan sesuai dengan rencana.

\section{Tahap Observasi/Pengumpulan Data}

Hasil perolehan skor/nilai selama pembinaan pada siklus I peneliti memperoleh skor rata-rata $(3,40)$ dari indikator keberhasilan yang direncanakan yaitu $\geq 4,0$. Perolehan skor rata-rata aktifitas peserta pembinaan pada siklus I yaitu $(3,33)$ dari indikator keberhasilan $(\geq 4,0$ 
). Perolehan nilai rata-rata hasil kerja guru dalam perancangan pembelajaran secara individual memperoleh rata-rata $(69,08)$ dari indikator keberhasilan $\geq 80,0$ (kategori baik). Dari 6 (enam) guru peserta pembinaan pada siklus I belum ada satu guru pun yang dinyatakan memperoleh nilai rata-rata $\geq 80,00$. Ini artinya pada siklus I presentasi pencapaian hasil kerja individual masih 0 , dalam arti belum ada yang tuntas sesuai indikator yang telah ditetapkan. Pada kegiatan siklus berikutnya peneliti harus mampu memotivasi peserta pembinaan dalam upaya mencapai indikator keberhasilan sebagai dampak nyata dari hasil pembinaan.

\section{Tahap Refleksi}

Perolehan skor rata-rata hasil observasi kepala sekolah selama proses pembinaan baru memperoleh skor rata-rata $(3,40)$, sementara perolehan hasil observasi peserta pembinaan sebagai aktifitas peserta selama pembinaan baru memperoleh skor rata-rata $(3,33)$, dan nilai ratarata hasil perancangan pembelajaran baru mencapai nilai rata-rata $(69,08)$. Dari perolehan hasil dimaksud peneliti merenung mencari faktor kendala dan penyebab sehingga hasil masil belum optimal. Dari hasil renungan itu akhirnya peneliti menemukan solusi untuk dapat dilaksanakan pada kegiatan pembinaan siklus berikutnya.

\section{SIKLUS II}

\section{Tahap Perencanaan}

Kesalahan-kesalahan yang terjadi pada siklus I sudah diperbaiki pada siklus II, sehingga pada tahapan ini peneliti bisa melakukan dengan baik. Kegiatan pada tahap perencanaan ini meliputi; 1) penyempurnaan penyusunan materi pembinaan, 2) perbaikan skenario/strategi/langkah-langkah pembinaan yang mengarah kepada peserta aktif, 3) menetapkan instrumen observasi kepala sekolah dan instrumen observasi guru, 4) menentukan jadwal kegiatan dan menetapkan pedoman analisa data hasil observasi dan hasil kerja individual.

Jurnal Ilmiah Mandala Education

\section{Tahap Pelaksanaan}

Pada tahapan ini, peneliti terlebih dahulu melakukan refleksi atas capaian hasil yang diperoleh pada siklus I. Kendala-kendala dan permasalahan yang terjadi dibahas sampai semua peserta pembinaan memahami dan menyadari akan kekurangan, kesalahan dan halhal yang bersifat krusial dapat dipecahkan pada saat kegiatan refleksi. Kegiatan selanjutnya peneliti menyampaikan materi pembinaan secara perlahan-lahan, ringkas dan jelas sehingga peserta pembinaan lebih paham dan mengerti tata cara perancangan pembelajaran.

\section{Tahap Observasi}

Pada siklus II perolehan skor rata-rata hasil observasi kepala sekolah adalah $(4,60)$ dari indikator keberhasilan $\geq 4,00$, ini artinya menunjukkan peningkatan yang sangat signifikan bila dibandingkan dengan perolehan hasil pada siklus I. Skor rata-rata hasil observasi guru yaitu aktifitas selama pembinaan dalam forum KKG memperoleh skor rata-rata $(4,67)$ dari indikator keberhasilan $\geq 4,00$. Dari hasil ini nampak nyata bahwa aktifitas peserta pembinaan pada siklus II mengalami peningkatan yang sangat tajam karena sudah mampu melampaui indikator keberhasilan yang telah ditetapkan. Nilai rata-rata hasil kerja individual dalam perancangan pembelajaran yakni $(90,19)$ dari indikator keberhasilan ( $\geq$ 80,00).

\section{Tahap Refleksi}

Berdasarkan hasil akhir perolehan skor rata-rata observasi kepala sekolah dan observasi guru serta hasil kerja individual perancangan pembelajaran semuanya telah melampaui indikator keberhasilan maka dapat disimpulkan bahwa: 1) upaya untuk menyempurnakan materi pembinaan dinyatakan berhasil, 2) pelaksanaan untuk memperbaiki strategi penyampaian materi tata cara penyusunan rancangan pembelajaran dan strategi pembinaan telah mampu meningkatkan motivasi dan kinerja guru sehingga perolehan hasil yang diharapkan dapat tercapai, 3) upaya untuk mengoptimalkan pelaksanaan pembinaan 
individual telah membawa dampak positif terhadap perolehan hasil dalam perancangan pembelajaran.

Karena semua indikator keberhasilan telah tercapai maka penelitian tindakan sekolah dihentikan pada siklus II dan dinyatakan berhasil memotivasi guru untuk lebih bergairah dan lebih bersemangat dalam upaya perancangan pembelajaran. Penelitian Tindakan Sekolah dengan judul "Peningkatan Kinerja Guru Dalam Perancangan Pembelajaran Melalui Supervisi Akademik Kepala SD Negeri 10 Cakranegara Semester Satu Tahun Pelajaran 2018/2019", dinyatakan "BERHASIL"”

\section{KESIMPULAN}

Perolehan data selama penelitian dapat dipaparkan sebagai berikut:

\begin{tabular}{|l|l|c|c|c|c|}
\hline \multirow{2}{*}{ No } & \multicolumn{1}{|c|}{ Jenis Kegiatan } & Indikator & \multicolumn{2}{|c|}{ Perolehan } & \multirow{2}{*}{ Ket } \\
\cline { 4 - 5 } & & Keberhasilan & Siklus I & Siklus II & \\
\hline 1. & Hasil Observasi Kepala Sekolah & $\geq 4,00$ & 3,40 & 4,60 & Tuntas \\
\hline 2. & Hasil Observasi Guru & $\geq 4,00$ & 3,33 & 4,67 & Tuntas \\
\hline 3. & Hasil Kerja Individual & $\geq 80,00$ & 69,08 & 90,19 & Tuntas \\
\hline
\end{tabular}

Pelaksanaan pembinaan berbasis $\mathrm{KKG}$ sangat efektif untuk meningkatkan kompetensi guru dalam perancangan pembelajaran bagi guru kelas 6 (enam) guru SD Negeri 10 Mataram dalam perancangan pembelajaran. Hal ini dibuktikan meningkatnya perolehan hasil observasi dan hasil kerja individual dari siklus I ke siklus II. Penelitian tindakan sekolah (PTS) ini dinyatakan berhasil dan dihentikan pada siklus II.

\section{SARAN}

Disarankan kepada rekan kepala sekolah lain untuk melakukan pembinaan dengan semua guru mata pelajaran dibawah binaan pada sekolah masing-masing dalam upaya meningkatkan kompetensinya khususnya dalam perancangan pembelajaran yang bisa diterapkan dalam proses pembelajaran di kelas senyatanya. Dampak yang diharapkan yaitu meningkatnya kualitas/mutu peserta didik di sekolah binaan melalui proses pembelajaran yang dilandasi dengan perancangan pembelajaran.

Kepada seluruh guru SD Negeri 10 Mataram disarankan untuk membiasakan melakukan musyawarah bersama dalam forum
KKG mata pelajaran yang diampunya, khususnya dalam perancangan pembelajaran, sehingga berdampak meningkatnya kompetensi guru dalam proses pembelajaran di kelas senyatanya dan pada gilirannya prestasi belajar peserta didik dapat ditingkatkan.

\section{DAFTAR PUSTAKA}

Arikunto, Suharsini. 2007. Penelitian Tindakan Kepengawasan. Bandung: Remaja Rosdakarya

Bellon, J.J., \& Bellon, E. C. 1982. Classroom Supervision and Intructional Improvement : A Synergetic Process $\left(2^{\text {nd }}\right.$ ed.). Dubuque, IA: Kendall/Hunt.

Cogan, Morris. 1973. Academic Supervision. Boston. Holt, Reinhart and Winston.

Costa, A.L., \& Garmston, R.J. 1994. Cognitive Coaching: A Foundation for Renaissance Schools. Norwood, MA: ChristopherGordon.

Depdikbud. 1984. Program AKta Mengajar V$B$ Komponen Dasar Pendidikan: Penilaian Program Pendidikan. Jakarta: Universitas Terbuka.

Glickman, C.D.. 1990. Supervision and Instructional Leadership A Development Approach. Seventh Edition. Boston: Allyn and Bacon.

Goldhammer, R. 1969. Academic Supervision: Special Methods For The Supervision Of Teachers. New York: Hlot, Reinhart and Winston.

Hamalik, Oemar. 2002. Psikologi Belajar Dan Mengajar. Bandung: Sinar Baru.

Harris, B. M. 1975. Supervisory Behavior In Education (2nded). Englewood Cliffs, NJ: Prentice-Hall.

McGreal, T. 1983. Effective Teacher Evalution. Alexandria, V A: Association For Supervision An Curriculum.

Mosher, R.L., \& Purpel, D.E. 1972. Supervision: The Reluctant Profession. Boston: Houghton-Mifflin.

Nanang Fattah. 1996. Landasan Manajemen Pendidikan. Bandung: Remaja Rosdakarya. 
Pajak, E. F. 1993. Approaches To Academic Supervision: Alternatives For Improving Instruction. Norwood, MA: ChristopherGordon.

Peraturan Pemerintah No. 19 Tahun 2005

Permendikbud No. 20 Tahun 2016 Tentang Standar Kompetensi Lulusan (SKL)

Permendikbud No. 21 Tahun 2016 Tentang Standar Isi

Sergiovanni, T.J., \& Starratt, R.J. 1998. Supervision: A Re-Definition ( $6^{\text {th }}$ ed). Boston: McGraw-Hill.

Sullivan, S. \& Glanz, J. 2005. Supervision that Improving Teaching Strategies and Techniques. Thousand Oaks, California: Corwin Press.

Sullivan, S \& Glanz, J. 2000. Alternative Approaches To Supervision: Cases From The Field. Journal Of Curriculum and Supervision, 15(3), 212-235. Thousand Oaks, California: Corwin Press.

Supriadi, Dedi. 1998. Mengangkat Citra Dan Martabat Guru. Yogyakarta: Adicita Karya Nusantara.

Unruh, A., \& Turner, H.E. 1970. Supervision For Change And Innovation. Boston: Houghton-Mifflin.

Widyastono, Herry. 1999. Kinerja Guru. Jurnal Pendidikan Dan Kebudayaan No. 20 Tahun ke-5, Desember. 